
СОЦІАЛЬНО-ПСИХОЛОГІЧНІ ОСОБЛИВОСТІ СТАВЛЕННЯ ДО ПАНДЕМІЇ
У ПРЕДСТАВНИКІВ РІЗНИХ СОЦІАЛЬНИХ ГРУП

\title{
SOCIO-PSYCHOLOGICAL FEATURES OF THE ATTITUDE TO THE PANDEMIC IN REPRESENTATIVES OF DIFFERENT SOCIAL GROUPS
}

У статті розглянуто соціально-психологічні особливості ставлення до пандемії у представників різних соціальних груп. Викладено теоретичні основи дослідження - роботи вчених, які визначають поняття «соціальна група» та досліджують проблеми пандеміі COVID-19. Проведено опитування серед студентів медичних спеціальностей та студентів технічних спеціальностей міста Одеси та Одеської області щодо їхнього ставлення до пандемії COVID-19. Основну увагу приділено рівню тривожності, схильності до депресивних симптомів та емоційному самопочуттю представників соціальних груп, а також різниці у їхньому сприйнятті ситуації пандемії.

Метою статmіє дослідження соціально-пси хологічних особливостей ставлення до пандемії студентів медичних спеціальностей та студентів технічних спеціальностей. Об'єктом дослідження є ставлення до пандемії різних соціальних груп; предметом - сочіально-психологічні особливості ставлення до пандемії у представників різних соціальних груп.

У висновках представлено розгляд теоретико-методологічних підходів до соціально-психологічного вивчення ставлення до пандемії; дослідження індивідуально-психологічних особливостей представників різних соціальних груп; аналіз на основі отриманих статистичних даних ставлення до пандемі (COVID-19) у представників різних соціальних груп.

УДК 159.922:316.35-057.875]:616-036.21 DOI https://doi.org/10.32843/2663-

5208.2021.25.33

\section{Коваль Г.ш.}

к.психол.н., доцент,

доцент кафедри соціальної і прикладної психології

факультету психології та соціальної роботи

Одеський національний університет імені І.І. Мечникова

Русінова 0.0.

студентка фракультету психології та соціальної роботи

Одеський національний університет

імені І.І. Мечникова демія, COVID-19, рівень тривожності, депресивний стан.

The article considers the socio-psychological features of the attitude to the pandemic in representatives of different social groups. The theoretical foundations of the study are presented - the work of scientists who define the concept of social group and investigate the problems of the COVID-19 pandemic. The author conducted a survey among medical students and technical students of the city of Odessa and Odessa region about their attitude to the COVID-19 pandemic. The focus is on the level of anxiety, predisposition to depressive symptoms and emotional well-being of members of social groups, as well as the difference in their perception of the pandemic situation.

The aim of the article is to study the socio-psychological features of the attitude to the pandemic of medical students and technical students.

The object of the study is the attitude to the pandemic of different social groups; subject socio-psychological features of the attitude to the pandemic in representatives of different social groups.

The conclusions present a consideration of theoretical and methodological approaches to the socio-psychological study of attitudes to the pandemic; research of individual psychological features of representatives of different social groups; analysis, based on the obtained statistical data, of the attitude to the pandemic (COVID-19) among representatives of different social groups. Today, at the household level, it is known that people around the world react unequally to a pandemic. One part of humanity reacts sharply to the problem with panic and follows all the recommended safety measures, leading to absurdity.

Some sections of the population do not even acknowledge the existence of a pandemic and deny that it really exists, even despite global statistics.

Perhaps not only a large category of the population treats the pandemic realistically, without going to extremes in either direction.

However, in the two years of the pandemic problem, there have been virtually no studies of the attitude to the pandemic from the standpoint of psychologists.

Key words: socio-psychological features, social group, attitude, pandemic, COVID-19, level of anxiety, depressed state.
Пандемія коронавірусної хвороби COVID19 стала величезною проблемою людства за останні два роки. Спалах захворювання розпочався у грудні 2019 р. у м. Ухань, Хубей, КНР, та визнаний ВООЗ пандемією 11 березня 2020 р. Станом на 21 лютого 2021 р. 111434139 випадків майже у всіх країнах та територіях. Унаслідок захворювання 2467481 особа померла, 62896305 людей одужало. За статистикою на 27 квітня 2021 р. в Україні нараховується 2038248 осіб, які захворіли на коронавірус, із них хвороба закінчилася смертю - 42950.

Учених, якідосліджуютьпандемію COVID-19, у світі доволі багато: Е. Лавеццо, Жоржи Калил, К. Андерсен, К. Купершвід, Ким Чен Йон, Ли Веньлян, Майк Фарзан, Эмма Ходкрофт, Юн-Джень Чан та ін. Вони переважно є лікарями і досліджують COVID-19 із погляду впливу на імунітет людини, його розповсю- 
дження, залежність віку людини та ймовірності до захворювання, вишукують варіанти лікування пацієнтів тощо.

Серед вітчизняних учених, які досліджують пандемію, - А.А. Остапенко, Д.М. Афанасьєв, К.Я. Новосад, Р.І. Джуган, Т.Н. Шушунова, Ш.Р. Басиров та багато інших. Вони досліджують різні аспекти впливу пандемії із соціально-психологічного, економіко-правового, етичного поглядів. Але за два роки існування проблеми пандемії дослідження ставлення до пандемії представників різних соціальних груп практично відсутні, що й зумовлює актуальність дослідження.

Метою статті $€$ дослідження соціально-психологічних особливостей ставлення до пандемії студентів медичних спеціальностей та студентів технічних спеціальностей.

Завдання дослідження: 1) розглянути теоретико-методологічні підходи до соціальнопсихологічного вивчення ставлення до пандемії; 2) дослідити індивідуально-психологічні особливості представників різних соціальних груп; 3) проаналізувати ставлення до пандемії (COVID-19) у представників різних соціальних груп.

Об'єкт дослідження: ставлення до пандемії різних соціальних груп. Предмет дослідження: соціально-психологічні особливості ставлення до пандемії у представників різних соціальних груп.

Методи дослідження, які було використано під час написання статті: теоретичні (аналіз і синтез джерел наукової літератури); авторська анкета ставлення до пандемії COVID-19; психодіагностичні: опитувальник депресії А.Т. Бека, тест диференціальної самооцінки функціонального стану опитувальник САН (самопочуття, емоції, настрій), оцінка рівня ситуативної (реактивної) тривожності тест Спілбергера - Ханіна, авторська анкета ставлення до пандемії; контент-аналіз для складення уявлення про ставлення до пандемії у досліджуваних соціальних груп.

Соціальною групою можна вважати людей однієї професії, які працюють або навчаються разом, або навчаються за одним фахом та спеціалізацією. Під це визначення підходять студенти різних спеціальностей, і можна виокремити студентів медичного фаху та студентів технічного напряму у дві різні соціальні групи за їх сумісною причетністю до типових форм діяльності.

Соціальна група містить свої характерні ознаки, за якими соціальна група відрізняється від звичайних груп.

Нині існує постійно збільшувана кількість досліджень стосовно теми пандемії COVID-19, проте дослідження пандемії розпочалося задовго до цього. У світі було декілька пандемій, які визначаються величезною смерт- ністю, економічними збитками, розголосом тощо, наприклад чума, холера, іспанка, грип, ВІЛ/СНІД, пандемія коронавірусної хвороби. I хоча у цій роботі висвітлено тему саме пандемії COVID-19, для кращого розуміння систематизації даних про вивчення пандемії важливим буде оглядове знайомство з інформацією щодо досліджень пандемій, які не відносяться поточної пандемії.

$€$ декілька підходів до вивчення пандемії, серед них можна виділити такі: дослідження пандемії як соціально-філософського феномена; дослідження феномену пандемії як такого; дослідження різниці пандемії та епідемії; цивілізаційне дослідження пандемії; дослідження пандемії із цивілізаційного погляду; дослідження пандемії з релігійно-культурного погляду; роль війн у появі пандемії; дослідження проблематики культурно-генетичних витоків феномена пандемії; системний підхід до розгляду пандемії; розкриття антисистемної природи пандемії тощо [2].

За допомогою опитування, яке проводилося в онлайн-форматі в мережі Інтернет за допомогою сервісу Google-форми (Google Forms), було проведено опитування серед представників двох цих соціальних груп. У ньому участь взяли студенти медичних та технічних спеціальностей у загальній кількості 60 осіб віком від 19 до 26 років.

Спочатку респондентам було надано авторське анкетування, яке дає змогу отримати загальний статистичний матеріал (вік, стать тощо) та отримати загальне розуміння про ставлення до пандемії COVID-19. Серед питань були такі:

- Ваш вік?

- Ваша стать?

- Чи Ви перехворіли на COVID-19?

- Чи Ви знаходилися під час пандемії на самоізоляції?

- Чи існує пандемія насправді?

- Причини виникнення пандемії?

- Які засоби для попередження захворювання на COVID-19 Ви використовуєте?

- Чи Ви плануєте робити щеплення від COVID-19?

Таке анкетування надає матеріал для статистичного аналізу ставлення до пандемії двох соціальних груп вибірки та дає змогу проаналізувати відмінності ставлення до пандемії у представників різних соціальних груп

Статистичний аналіз та контент-аналіз отриманих даних демонструє такі результати.

Серед опитаних респондентів у першій виборці студентів-медиків відсоткова частка жінокстановила 76,9\% (23жінки із 30 опитаних), чоловіків - 23,1\% (7 чоловіків із 30 опитаних).

Вік респондентів має діапазон від 19 до 26 років. Серед опитаних із першої вибірки $53,8 \%$ респондентів на момент проведення 
опитування не перехворіли на COVID-19, при тому що 46,2\% опитаних на момент опитування вже перехворіли на коронавірусну хворобу. Серед представників вибірки студентів-медиків $89,1 \%$ опитаних знаходилися на самоізоляції і тільки 9,9\% не дотримувалися самоізоляції. 100\% опитаних серед першої вибірки впевнені у існуванні пандемії, жоден респондент не виказав сумнівів щодо існування пандемії або ж не став заперечувати її існування.
Серед опитаних із першої вибірки планують робити щеплення від COVID-19 п'ять опитаних $(17,5 \%)$, шість $(19,8 \%)$ не планують робити щеплення, а 19 респондентів $(62,7 \%)$ не визначилися або мають сумніви щодо відповіді на це питання. 26 респондентів (85,8\%) уважають, що причиною пандемії став кажан, жоден із респондентів не вважає, що пандемії не існує й усе це змова, чотири респонденти $(14,2 \%)$ надають у відповіді свої думки щодо

Таблиця 1

Загальні дані за вибіркою студентів-медиків та результати авторського анкетування

\begin{tabular}{|l|c|}
\hline \multicolumn{1}{|c|}{ Дані по виборці студентів-медиків } \\
\hline Жінки & $23(76,9 \%)$ \\
\hline Чоловіки & $7(23,1 \%)$ \\
\hline Перехворіли на COVID-19 & $14(46,2 \%)$ \\
\hline Не перехворіли на COVID-19 & $16(53,8 \%)$ \\
\hline Знаходилися на самоізоляції & $27(89,1 \%)$ \\
\hline Не знаходилися на самоізоляції & $3(9,9 \%)$ \\
\hline Вважають, що пандемія існує & $30(100 \%)$ \\
\hline Вважають, що пандемії не існує & 0 \\
\hline Мають сумніви щодо існування пандемії & 0 \\
\hline Планують робити щеплення від COVID-19 & $5(17,5 \%)$ \\
\hline Не планують робити щеплення від COVID-19 & $6(19,8 \%)$ \\
\hline Не визначилися або дають свою відповідь щодо щеплення & $19(62,7 \%)$ \\
\hline Вважають, що причиною виникнення пандемії СОVID-19 став кажан & $26(85,8 \%)$ \\
\hline Вважають, що пандемії не існує і це змова & 0 \\
\hline Висловлюють свої думки щодо виникнення пандемії СОVID-19 & $4(14,2 \%)$ \\
\hline $\begin{array}{l}\text { Використовували захисні матеріали для попередження захворювання } \\
\text { на COVID-19 (маску, антисептичні засоби, рукавички тощо) }\end{array}$ & $30(100 \%)$ \\
\hline $\begin{array}{l}\text { Не використовували захисні матеріали для попередження захворювання } \\
\text { на COVID-19 (маску, антисептичні засоби, рукавички тощо) }\end{array}$ & 0 \\
\hline
\end{tabular}

Загальні дані за вибіркою студентів технічних спеціальностей та результати

Таблиця 2 авторського анкетування

\begin{tabular}{|l|c|}
\hline \multicolumn{2}{|c|}{ Дані по виборці студентів технічних спеціальностей } \\
\hline Жінки & $10(33 \%)$ \\
\hline Чоловіки & $20(77 \%)$ \\
\hline Перехворіли на COVID-19 & $12(39,6 \%)$ \\
\hline Hе перехворіли на COVID-19 & $18(60,4 \%)$ \\
\hline Знаходилися на самоізоляції & $14(46,2 \%)$ \\
\hline Не знаходилися на самоізоляції & $16(53,8 \%)$ \\
\hline Вважають, що пандемія існує & $25(82,5 \%)$ \\
\hline Вважають, що пандемії не існує & $2(6,6 \%)$ \\
\hline Мають сумніви щодо існування пандемії & $3(10,9 \%)$ \\
\hline Планують робити щеплення від COVID-19 & $2(6,6 \%)$ \\
\hline Не планують робити щеплення від COVID-19 & $23(75,9 \%)$ \\
\hline Дають свою відповідь або не визначилися щодо щеплення & $5(17,5 \%)$ \\
\hline Вважають, що причиною виникнення пандемії СОVID-19 став кажан & $26(86,8 \%)$ \\
\hline Вважають, що пандемії не існує і це змова & $2(6,6 \%)$ \\
\hline Висловлюють свої думки щодо виникнення пандемії СОVID-19 & $2(6,6 \%)$ \\
\hline $\begin{array}{l}\text { Використовували захисні матеріали для попередження захворювання } \\
\text { на СОVID-19 (маску, антисептичні засоби, рукавички тощо) }\end{array}$ & $24(80,2 \%)$ \\
\hline $\begin{array}{l}\text { Не використовували захисні матеріали для попередження захворювання } \\
\text { на COVID-19 (маску, антисептичні засоби, рукавички тощо) }\end{array}$ & $6(19,8 \%)$ \\
\hline
\end{tabular}


виникнення пандемії, серед їхніх відповідей $€$ такі: «Сукупність закономірних і випадкових обставин»; «Дослідження в Китаї», «Лабораторні дослідження в Китаї», «Кажуть, що першопричиною могли стати продажі кажанів у Китаї, проте можуть бути й інші ще не досліджені варіанти».

Серед опитаних другої вибірки, якою стали студенти технічних спеціальностей, відсоткова частка жінок становила 33\% (10 жінок серед 30 опитаних), 77\% - чоловіки (20 чоловіків із 30 опитаних). Із них 12 (77\%) на момент проведення опитування вже перехворіли на коронавірусну хворобу, а 18 (60,4\%) не перехворіли на COVID-19. Віковий діапазон вибірки - від 19 до 21 року. Опитані даної вибірки, які знаходилися на самоізоляції, становлять 46,2\% (14 респондентів із 30 опитаних), 53,8\% (16 респондентів із 30 опитаних) не знаходилися на самоізоляції під час пандемії. Студенти технічних спеціальностей, які вважають, що пандемія дійсно існує, становить 25 респондентів (82,5\%) від кількості усіх опитаних другої вибірки, натомість два респонденти (6,6\%) вважають, що пандемії не існує, три респонденти (10,9\%) мають сумніви щодо реального існування пандемії. Два респонденти (6,6\%) планують робити щеплення від COVID-19; 23 респонденти (75,9\%) не планують робити щеплення від COVID-19; при цьому п'ять респондентів $(17,5 \%)$ не визначилися, робити щеплення чи ні, або ж надають свою відповідь. Серед відповідей респондентів щодо щеплення проти COVID-19 є такі: «Якщо примусять, то зроблю, взагалі не планую», «Зроблю, якщо від неї ніхто не помре». Наступним питанням було «Що стало причиною початку пандемії COVID-19?».

Серед респондентів другої вибірки студентів технічних спеціальностей 26 респондентів (86,8\%) уважають, що причиною появи пандемії став кажан; при цьому два респонденти (6,6\%) вважають, що пандемії не існує й усе це змова, а ще два респонденти (6,6\%) мають свої думки щодо виникнення пандемії. Серед відповідей респондентів щодо того, що стало причиною виникнення пандемії COVID-19, є такі: «Невідомо», «Важко відповісти на це питання».

За результатами трьох подальших методик можна виявити таку статистику. Студенти медичних спеціальностей за методикою САН виявили такі результати:

1. За шкалою «Самопочуття»:

А. Низькі показники: 4 респонденти (13,2\%).

Б. Середні показники: 7 респондентів $(23,1 \%)$.

В. Високі показники: 19 респондентів $(63,7 \%)$.

2. За шкалою «Активність»:

А. Низькі показники: 4 респонденти (13,2\%).

Б. Середні показники: 10 респондентів (33\%).
В. Високі показники: 16 респондентів $(53,8 \%)$.

3. За шкалою «Настрій»:

А. Низькі показники: 1 респондент (3,3\%).

Б. Середні показники: 7 респондентів $(23,1 \%)$.

В. Високі показники: 22 респонденти (73,6\%).

Натомість студенти технічних спеціальностей виявили такі результати за методикою САН:

За шкалою «Самопочуття»:

А. Низькі показники: 0 респондентів (0\%).

Б. Середні показники: 13 респондентів $(42,9 \%)$.

В. Високі показники: 17 респондентів $(57,1 \%)$.

2. За шкалою «Активність»:

А. Низькі показники: 5 респондентів (16,5\%).

Б. Середні показники: 19 респондентів $(62,7 \%)$.

В. Високі показники: 6 респондентів (20,8\%).

3. За шкалою «Настрій»:

А. Низькі показники: 1 респондент (3,3\%).

Б. Середні показники: 21 респондент $(69,3 \%)$.

В. Високіпоказники: 8 респонденти $(27,4 \%)$.

Аналіз отриманих результатів за тестуванням Спілбергера - Ханіна у студентів медичних спеціальностей демонструє такі показники.

1. Низький рівень тривожності: 15 респондентів (49,5\%).

2. Помірний рівень тривожності: 13 респондентів (43,9\%).

3. Високий рівень тривожності: 1 респондент (3,3\%).

4. Дуже високий рівень тривожності: 1 респондент (3,3\%).

Натомість статистична картина результатів студентів технічних спеціальностей за тією ж самою методикою виглядає так:

1. Низький рівень тривожності: 4 респонденти (14,2\%).

2. Помірний рівень тривожності: 26 респондентів (85,8\%).

3. Високий рівень тривожності: 0 респондентів (0\%).

4. Дуже високий рівень тривожності: 0 респондентів (0\%).

Останньою методикою, яку було використано в досліджені, є шкала депресії Бека.

Студенти медичних спеціальностей із першої вибірки показали такі результати:

1. Відсутність депресивних симптомів: 10 респондентів (33\%).

2. Легкі депресивні симптоми (субдепресія): 9 респондентів (29,7\%).

3. Помірний рівень депресивних симптомів: 8 респондентів $(27,4 \%)$.

4. Виражені депресивні симптоми (середньої тяжкості): 1 респондент (3,3\%).

5. Тяжкі депресивні симптоми: 2 респонденти (6,6\%). 
Наступні результати було продемонстровано студентами технічних спеціальностей із другої вибірки:

1. Відсутність депресивних симптомів: 15 респондентів (49,5\%).

2. Легкі депресивні симптоми (субдепресія): 11 респондентів (37,3\%).

3. Помірний рівень депресивних симптомів: 0 респондентів (0\%).

4. Виражені депресивні симптоми (середньої тяжкості): 3 респонденти (9,9\%).

5. Тяжкі депресивні симптоми: 1 респондент (3,3\%).

За результатами дослідження виявлено, що представники обох груп демонструють різні результати. Представники різних соціальних груп ставляться до проблеми по-різному. Їхній психоемоційний стан зовсім різний. Якщо видно, що у студентів медичних спеціальностей відсутні депресивні симптоми у $33 \%$ вибірки, то у студентів технічних спеціальностей цей відсотковий показник становить 49,5\%. Проте цікавим $є$ той факт, що ситуаційна тривожність знаходиться у низькому діапазоні показників у студентів медичних спеціальностей у 49,5\% від вибірки, тоді як у студентів технічних спеціальностей цей показник становить лише $14,2 \%$. Можливо, це пов'язано з тим, що студенти медичних закладів у $100 \%$ випадків упевнені у існуванні пандемії, тоді як студенти технічних спеціальностей продовжують із недовірою ставитися до існуючих фактів. У них виникають думки щодо того, що пандемія може бути змовою або що її взагалі не існує. В умовах даного дослідження саме це може мати впив на той факт, що студенти технічних вишів хоча і мають за статистикою менше проявів депресивних симптомів, при цьому їхній рівень тривожності здебільшого не $є$ високим, проте знаходиться на помірному рівні.
Індивідуально-психологічні особливості двох груп вказали на наявність певних закономірностей за методикою САН. Їхні показники самопочуття переважають у високому діапазоні, тоді як настрій та активність знаходяться у середньому діапазоні, що відображає, що ставлення до пандемії у загальній вибірці може характеризуватись як менш активне і менш веселе. Також було проведено статистичний аналіз тестувань за методикою Спілбергера Ханіна та Бека.

Аналіз ставлення до пандемії COVID-19 у представників різних соціальних груп надав картину того, що студенти медичних спеціальностей хоча у середньому і мають вищий бал, проте кількість респондентів у вибірці, які потрапляють у діапазон низької тривожності, є більшим. Це може свідчити про більшу ix поінформованість про проблему, натомість студенти технічних спеціальностей переважно знаходяться у діапазоні помірної тривожності, що вказує на їх недостатню поінформованість, адже частка вибірки заперечує існування пандемії та веде себе так, наче нічого не відбувається.

\section{ЛІТЕРАТУРА:}

1. Орбан-Лембрик Л.Е. Соціальна психологія : підручник : у 2-х кн. Кн. 2. Соціальна психологія груп. Прикладна соціальна психологія. Київ : Либідь, 2006. $560 \mathrm{c}$.

2. Луканова В.В. Феномен пандемії: підґрунтя, сутність, динаміка : дис. ... канд. фріл. наук : 09.00.03. Дніпро, 2019. С. 9-23.

3. Wagner P. COVID-19, HIVIAIDS, and the "Spanish Flu": Historical Moments and Social Transformations. Thesis Eleven, July 24, 2020. URL: http://thesiseleven. com/2020/07/24/covid-19-hiv-aids-and-the-spanishflu-historicalmoments-and-social-transformations (дата звернення: 25.04.2021). 